\title{
Antibacterial activity test of Simargaolgaol (Aglaonema modestum Schott ex Engl) leaves extract against Escherichia coli and Salmonella typhi bacteria
}

\author{
Tiurma Solomasi Zega', Putri Mandaoni Pakpahan', Rahmayani \\ Siregar ${ }^{1}$, Givinda Sitompul ${ }^{2}$ and Saronom Silaban ${ }^{3, *}$ \\ ${ }^{1}$ Chemistry Study Program, Universitas Negeri Medan, Medan 20221, Indonesia \\ ${ }^{2}$ Biology Education Study Program, University Negeri Medan, Medan 20221, Indonesia \\ 3 Department of Chemistry, Universitas Negeri Medan, Medan 20221, Indonesia \\ *Corresponding author: SS, saronomsilaban@unimed.ac.id
}

DOI: 10.24114/jpkim.v13i2.26989

Article history:

Received: 12 July 2021

Revised: 19 July 2021

Accepted: 21 July 2021

Abstract: The Simargaolgaol (Aglaonema modestum Schott ex Engl) plant is a plant that grows wild in Barus District, Central Tapanuli, North Sumatra which is used by the community as a medicinal plant. This study aims to determine the antibacterial activity of n-hexane, ethyl acetate and ethanol extracts from Simargaolgaol leaves against Escherichia coli and Salmonella typhi bacteria. The antibacterial activity test of Simargaolgaol leaves was carried out using the disc diffusion method. The results of antibacterial activity showed that the highest inhibitory power of Simargaolgaol leaf extract was ethanol extract (polar), ethyl acetate extract (semi polar) and n-hexane extract (non polar). The inhibitory power of ethanol extract, ethyl acetate, and $\mathrm{n}$-hexane against Escherichia coli bacteria was $13.1 \mathrm{~mm}$ (strong); $9.7 \mathrm{~mm}$ (medium); $8.0 \mathrm{~mm}$ (medium) and for Salmonella typhi bacteria respectively $11.2 \mathrm{~mm}$ (strong); $10.7 \mathrm{~mm}$ (strong) and $9.3 \mathrm{~mm}$ (medium). With the concentration of the extract in the diameter is $10 \%$. Based on this, it can be concluded that Simargaolgaol leaf extract has potential as an antibacterial.

Keywords: Aglaonema modestum Schott ex Engl, Antibacterial activity, Escherichia coli, Salmonella typhi

\section{Introduction}

Indonesia is one of the countries that has a wealth of nature with various kinds of medicinal plants in the world. After Brazil, Indonesia is a country that has tropical forest 
areas with the second highest biodiversity in the world. Among the 41,000 kinds of plants that exist throughout the world, in Indonesia there are 31,000 kinds that can be found, of which 950 species are reported to be used as medicine and have been used by various tribes in Indonesia. Of the total number of medicinal plants, about 90\% can be found in Asia (Masyhud, 2010).

Recently, the number of diseases caused by bacterial infection is increasing, especially in developing countries including Indonesia. Bacteria are infectious agents that cause the process of invasion and reproduction of microorganisms in body tissues. Based on this, it can be seen that bacteria are very detrimental to the sufferer's body if the propagation of microorganisms occurs beyond normal limits (Darsana, 2012; Febrina et al. 2017; Simorangkir et al. 2019a). One of the bacteria that can cause this infection is E. coli and S. typhi, which are gram-negative bacteria. Some bacteria have developed resistance to certain antibiotics. Therefore, alternative treatments that come from nature are becoming increasingly real (Sari et al. 2017).

One of the plants that has the potential for treatment is the Simargaolgaol (Aglaonema modestum Schott ex Engl) plant. The Simargaolgaol (Aglaonema modestum Schott ex Engl) plant is one of the plants that grows wild in the Barus forest area, Central Tapanuli, North Sumatra. The leaves of this plant are often used by local people as traditional medicine to cure inflammatory diseases, heart, kidney and wounds, especially rotting wounds. This research was focused on knowing the antibacterial activity of Simargaolgaol (Aglaonema modestum Schott ex Engl) leaf extract. Simargaolgaol plants have been taxonomically classified by Herbarium Medanese under number 5717, 2021 (Fig 1).

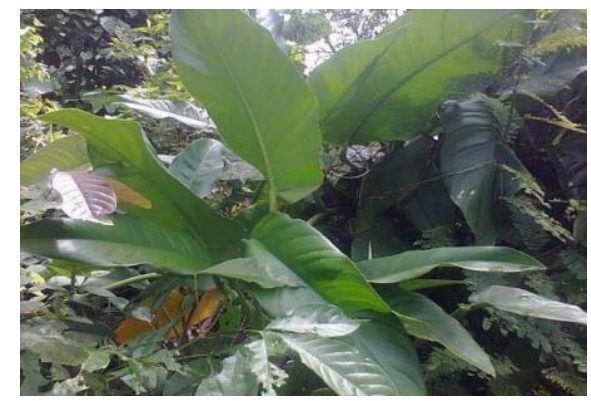

Fig 1. Simargaolgaol (Aglaonema modestum Schott ex Engl) plant

Previous studies reported that the secondary metabolite content of Aglaonema hookerianum ethanol extract showed the presence of alkaloids, glycosides, tannins, and saponins. The study also reported that the ethanol extract of Aglaonema hookerianum leaves had good inhibitory activity as antibacterial activity against several gram-positive bacteria (Bacillus subtilis, Bacillus megateriumm, Staphylococcus aureus) and gram-negative bacteria (Pseudomonas aeruginosa, Escherichia coli, Shigella dysenteriae, Salmonella typhi, Salmonella paratyphi, Vibrio cholera) (Roy et al. 2011).

\section{Methods}

\subsection{Materials and sample}

The main ingredients used were $n$-hexane extract, ethyl acetate extract and ethanol extract which had been previously macerated. The test bacteria used were Escherichia coli 
(ATCC 25922) and Salmonella typhi (ATCC 14028). Mueller Hinton Agar (MHA) obtained from Oxoid CM0337 was used as a medium for bacterial growth. Other materials used were Dimethyl Sulfoxide (DMSO) (Merck), physiological $\mathrm{NaCl} 0.9 \%, \mathrm{MC}$ Farland 0.5\%, Chloramphenicol (Oxoid), blank disc paper (Oxoid), whatman filter paper, aluminum foil.

\subsection{MHA media creation}

Weigh 38 grams of MHA media, then add $1000 \mathrm{~mL}$ of distilled water. Furthermore, all tools and materials were sterilized in an autoclave for 15 minutes at $1210 \mathrm{C}$. After that, the solution was put into a petri dish until evenly distributed, then the media was allowed to dry and solidify in laminar flow (Utomo et al. 2018).

2.3 Rejuvenation of E. coli and S. typhi bacteria

Escherichia coli (ATCC 25922) and Salmonella typhi (ATCC 14028) bacteria were cultured in sterilized petri dishes, then incubated for 24 hours at $37^{\circ} \mathrm{C}$ (Simorangkir et al. 2019b).

\subsection{Bacterial inoculum}

The bacterial culture was taken in one loop using a cotton bud and inoculated into a test tube containing $15 \mathrm{~mL}$ of $0,9 \%$ physiological $\mathrm{NaCl}$ then vortexed until the turbidity reached the McFarland standard of $0,5\left(1,5 \times 10^{8} \mathrm{CFU} / \mathrm{mL}\right)$ (Nurhayati et al. 2020).

\subsection{Variation of extract concentration}

Extract of Simargaolgaol leaves (n-hexane, ethyl acetate, ethanol) was dissolved in DMSO solvent to obtain a concentration of $1 \% ; 2,5 \% ; 5 \%$, and $10 \%$. For $10 \%$ of the extract, 0,1 gram was weighed and then put into a $1 \mathrm{~mL}(\mathrm{w} / \mathrm{v})$ micro tube then added DMSO solvent to the limit mark and then vortexed until homogeneous (Capriotti et al. 2012). After that, the dilution was carried out to a concentration of $5 \% ; 2,5 \%$; and $1 \%$.

\subsection{Disc diffusion method}

The disc diffusion method was started by dripping $100 \mathrm{~L}$ of bacterial suspension on the agar medium, then leveled using a spreader. Let stand until the suspension in the media to dry. Paper discs were immersed in the extract with the extract concentration treatment of $1 \% ; 2.5 \% ; 5 \%$, and $10 \%$ using tweezers, then placed the paper disc on the agar media. The same thing was done to DMSO solvent as a negative control (Mardiah et al. 2017). The positive control used was chloramphenicol 30 g directly placed on agar media (Natheer et al. 2012). Next, the plate was closed and put in an incubator for 24 hours at $37^{\circ} \mathrm{C}$. After 24 hours, each agar plate was examined for the clear zone formed by using a digital caliper to obtain the diameter of the inhibition zone formed (Mardiah et al. 2017).

\section{Results and Discussion}

The antibacterial activity test was carried out using the paper disc diffusion method, namely by soaking the disc paper in each extract and then pasting it on E. coli (ATCC 25922) and S. typhi (ATCC 14028) bacteria that had been grown on MHA (Oxoid CM0337) media. Antibacterial activity was measured from the diameter of the clear zone formed on MHA media. The extract samples used were n-hexane, ethyl acetate and ethanol extract of Simargaolgaol (Aglaonema modestum Schott ex Engl) leaves with varying concentrations of 1\%; 2.5\%; 5\%; and 10\% using DMSO as a negative control and chloramphenicol as a positive 
control. The solvent used to dilute the extract is a negative control, which aims to ensure that the solvent does not affect the activity test of the extract (Natheer et al. 2012).

The results of the activity test of n-hexane extract (Fig 2a), ethyl acetate extract (Fig 2b) and ethanol (Fig 2C) of Simargaolgaol leaves against Escherichia coli bacteria showed different inhibitory powers. From the results obtained, the largest clear zone diameter for each extract (n-hexane, ethyl acetate, and ethanol) was found at a concentration of $10 \%$ where at that concentration the ethanol extract (polar) obtained the largest clear zone diameter of $13.1 \mathrm{~mm}$, with ethyl acetate extract (semi polar) the diameter of the clear zone was $9.7 \mathrm{~mm}$ and with $\mathrm{n}$-hexane extract (non polar) the diameter was $8.0 \mathrm{~mm}$. The extent of inhibition of Simargaolgaol leaf extract against Escherichia coli bacteria can be determined by measuring the clear zone formed around the disc in Fig 2.

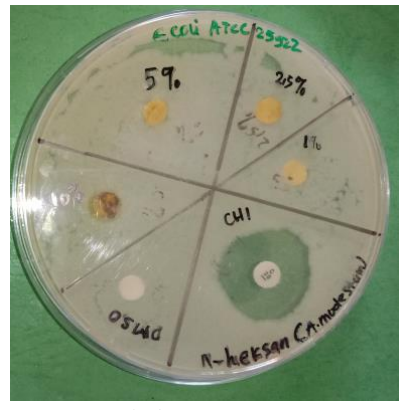

(a)

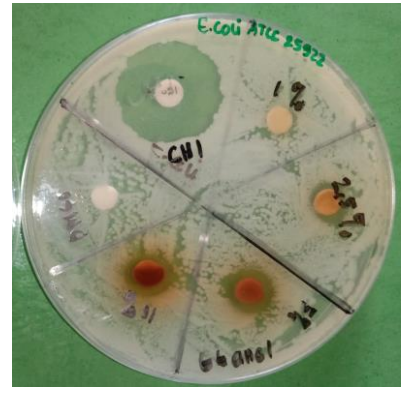

(b)

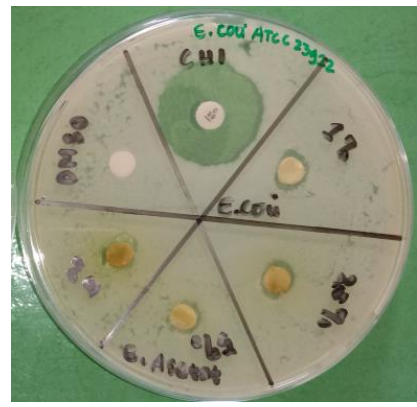

(c)

Fig 2. Antibacterial activity test results. (a) n-hexane extract, (b) ethyl acetate extract, (c) ethanol extract against Eschrichia coli

In the test of Simargaolgaol leaf extract against Salmonella typhi bacteria, all extracts namely n-hexane extract (Fig 3a), ethyl acetate extract (Fig 3b) and ethanol (Fig 3c) provided inhibition even though the diameters of the inhibition zones were different. From the results obtained, the diameter of the clear zone formed starting from the largest in sequence is the administration of $10 \%$ ethanol extract (polar) of $11.2 \mathrm{~mm}, 5 \%$ ethanol extract (polar) of $10.9 \mathrm{~mm}, 10 \%$ ethylacetate extract (semi-polar) of $10.7 \mathrm{~mm}$, ethanol extract of $2.5 \%$ (polar) of $10.3 \mathrm{~mm}, 5 \%$ ethylacetate extract (semi-polar) of $10.2 \mathrm{~mm}$, ethylacetate extract of 2.5\% (semi-polar) -polar) $10.1 \mathrm{~mm}$ and 10\% n-hexane extract (non-polar) $9.3 \mathrm{~mm}$. The extent of inhibition of Simargaolgaol leaf extract against $\mathrm{S}$. typhi bacteria formed around the disc is shown in Fig 3.

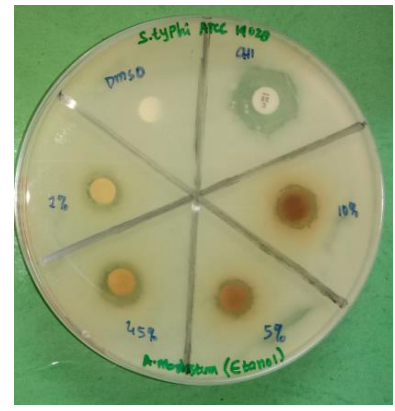

(a)

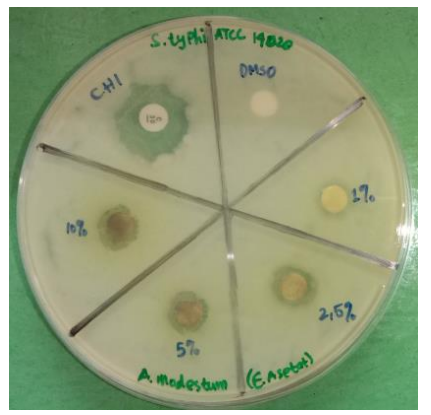

(b)

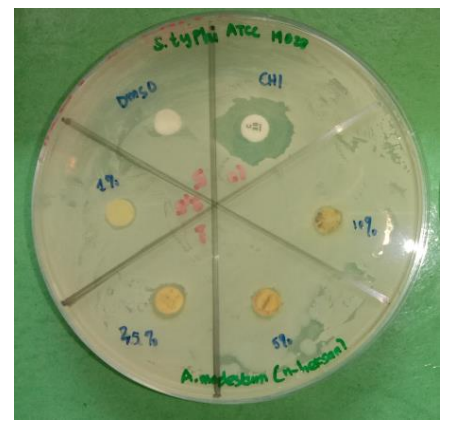

(c)

Fig 3. Antibacterial activity test results. (a) n-hexane extract, (b) ethyl acetate extract, (c) ethanol extract against $\mathrm{S}$. typhi 
From the results obtained on n-hexane extract, ethyl acetate extract and ethanol extract of Simargaolgaol leaves against Escherichia coli and Salmonella typhi bacteria with variations in concentration (1\%; $2.5 \%$; $\%$; $10 \%$ ) it can be seen that the higher the concentration variation, the higher the concentration variation. The resulting inhibition zone is wider. The antibacterial potential of Simargaolgaol extract was seen to be stronger at higher concentrations as well as research (Simorangkir et al. 2019; Situmeang et al. 2019; Juwitaningsih et al. 2021) which stated that the higher the concentration of the extract, the wider the diameter of the inhibition zone formed.

The formation of a clear zone around the test extract disc paper on agar media is caused by the content of secondary metabolites contained in each Simargaolgaol leaf extract which is able to inhibit the growth of bacteria around the test extract (Ernawati \& Hasmila, 2015). The n-hexane and ethyl acetate extracts had good antimicrobial activity against S.typhi bacteria compared to E. coli bacteria. This can be seen from the diameter of the inhibition zone formed where the diameter of the inhibition zone for n-hexane and ethyl acetate extracts against S. typhi was greater than the diameter of the inhibition zone for $E$. coli bacteria. Meanwhile, ethanol extract was more effective in inhibiting $E$. coli bacteria than $S$. typhi bacteria with a clear zone diameter formed for $E$. coli bacteria at a $10 \%$ extract concentration, namely $13.1 \mathrm{~mm}$ and $11.2 \mathrm{~mm}$ for $\mathrm{S}$. typhi bacteria.

In the classification of the category of bacterial inhibitory power by Davis \& Stout (1971) stated that if the diameter of the bacterial inhibition zone is equal to or smaller than $5 \mathrm{~mm}$ then it is weak, if the inhibition zone is at a diameter of 5-10 mm it is categorized as moderate, then if the inhibition zone is at $5-10 \mathrm{~mm}$ diameter is categorized as moderate. ranged from 10-20 mm, it was categorized as strong, whereas if the diameter of the bacterial inhibition zone was more than $20 \mathrm{~mm}$, it was categorized as very strong. From the results obtained, the diameter of inhibition by $n$-hexane extract from Simargaolgaol leaves could inhibit $E$. coli and S. typhi bacteria in the medium category because they had an inhibition zone of 5-10 mm. The diameter of inhibition by ethyl acetate extract against $E$. coli was moderate, while for S. typhi at a concentration of 2.5\%; $5 \%$ and $10 \%$ are classified as strong because they have an inhibition zone of $10-20 \mathrm{~mm}$. Ethanol extract at a concentration of $1 \%$ against bacteria $E$. coli and S. typhi was classified as moderate, while at a concentration of 2.5\%; $5 \%$ and $10 \%$ are classified as strong because they have an inhibition zone of $10-20 \mathrm{~mm}$. Based on the results of this study, DMSO gave negative results to all test bacteria. This proves that DMSO has no antibacterial activity. The results of the inhibition zone test can be seen in Table 1.

The ethanol extract (polar) of Simargaolgaol leaves has stronger antibacterial potential against Escherichia coli and Salmonella typhi compared to ethyl acetate extract (semi polar) and $\mathrm{n}$-hexane extract (non polar). This is because the results of the phytochemical screening of the ethanol extract of Simargaolgaol leaves that have been carried out previously showed that there were secondary metabolites of alkaloids, tannins, flavonoids, and saponins. The results of relevant studies show that alkaloids, tannins, flavonoids, (Cushnie \& Lamb, 2005), saponin compounds (Monte et al. 2014), have antibacterial potential, especially against common pathogenic bacteria. In addition, Escherichia coli and Salmonella typhi are Gram negative bacteria. Gram-negative bacteria are generally very sensitive to polar antibacterial compounds because the cell walls of gram-negative bacteria are polar so that it is easier for polar antibacterial compounds to pass (Pelczar \& Chan, 1988). Compounds in polar extracts 
can easily penetrate the cell walls of Gram-negative bacteria due to the presence of hydrophilic groups (Moat et al. 2002). The cell walls of Gram-negative bacteria contain a protein group called porin which forms hydrophilic pores on the outer cell membrane layer so that the polar compounds contained in the ethanol extract can more easily penetrate the cell walls of E. coli and S. typhi bacteria (Brooks, 2005).

Table 1

Observation result of inhibitory zone diameter of Simargaolgaol leaf extract against E. coli and S. typhi bacteria

\begin{tabular}{|c|c|c|c|}
\hline \multirow{2}{*}{$\begin{array}{c}\text { Simargaolgaol Leaf } \\
\text { Extract }\end{array}$} & \multirow[t]{2}{*}{ Concentration (\%) } & \multicolumn{2}{|c|}{$\begin{array}{l}\text { Average Inhibitory Zone Diameter } \\
\qquad(\mathrm{mm})\end{array}$} \\
\hline & & E. coli & S. typhi \\
\hline \multirow[t]{6}{*}{$\mathrm{N}$-Hexane } & Pc & 23.5 & 21.1 \\
\hline & $\mathrm{Nc}$ & 0 & 0 \\
\hline & $1 \%$ & 7.1 & 9.2 \\
\hline & $2.5 \%$ & 7.4 & $9 \cdot 3$ \\
\hline & $5 \%$ & 7.7 & $9 \cdot 3$ \\
\hline & $10 \%$ & 8.0 & $9 \cdot 3$ \\
\hline \multirow[t]{6}{*}{ Ethyl Acetate } & $\mathrm{Pc}$ & 24.5 & 19.1 \\
\hline & $\mathrm{Nc}$ & 0 & 0 \\
\hline & $1 \%$ & 7.5 & 7.5 \\
\hline & $2.5 \%$ & 8.9 & 10.1 \\
\hline & $5 \%$ & 9.1 & 10.2 \\
\hline & $10 \%$ & 9.7 & 10.7 \\
\hline \multirow[t]{6}{*}{ Ethanol } & $\mathrm{Pc}$ & 24.2 & 20.3 \\
\hline & Nc & 0 & 0 \\
\hline & $1 \%$ & 7.0 & 8.3 \\
\hline & $2.5 \%$ & 10.0 & 10.3 \\
\hline & $5 \%$ & 12.5 & 10.9 \\
\hline & $10 \%$ & 13.1 & 11.2 \\
\hline
\end{tabular}

Note: $\mathrm{Pc}=$ Positive Control (chloramphenicol); $\mathrm{Nc}=$ Negative control (DMSO)

According to Parekh et al. (2005) antibacterial activity is influenced by the polarity of the compound extracted by each solvent with the ability of these substances to spread on different media used in the antibacterial activity test. According to Schlegel (1993), each class of compounds can have a different effect in inhibiting bacterial growth. The difference in activity that occurs is caused by the secondary metabolites contained have different synergistic effects depending on the nature and morphology of the bacteria. Another factor that caused the difference in the diameter of the inhibition zone of the extract was the difference in the active compounds contained in the extract.

\section{Conclusion}

Extracts of $\mathrm{n}$-hexane, ethyl acetate and ethanol from Simargaolgaol (Aglaonema modestum Schott ex Engl) leaves have the ability to inhibit the activity of E. coli (ATCC 25922) 
and S. typhi (ATCC 14028). The highest inhibitory power were found in ethanol, ethyl acetate and $n$-hexane extracts, respectively. The inhibition of ethanol extract with a concentration of $10 \%$ was more effective on E. coli bacteria (ATCC 25922), which was $13.1 \mathrm{~mm}$, while S. typhi (ATCC 14028) was only $11.2 \mathrm{~mm}$.

\section{Acknowledgment}

Thank you to SIMBELMAWA Ministry of Education, Culture, Research and Technology of the Republic of Indonesia for funding PKM-RE with contract number 1126/UN33.III/KM/2021. The same remark was also conveyed to LPPM Unimed for the PNBP research funds on the Student Grant scheme with the contract number 0069/UN33.8/PL-PNBP/2021.

\section{References}

Brooks, G. F. (2005). Mikrobiologi kedokteran. Jakarta: Salemba Medika.

Capriotti, A. L., Cavaliere, C., Piovesana, S., Samperi, R., \& Laganà, A. (2012). Multiclass screening method based on solvent extraction and liquid chromatography-tandem mass spectrometry for the determination of antimicrobials and mycotoxins in egg. Journal of Chromatography A, 1268, 84-90. DOI:10.1016/j.chroma.2012.10.040

Cushnie, T. T., \& Lamb, A. J. (2005). Antimicrobial activity of flavonoids. International Journal of Antimicrobial Agents, 26(5), 343-356. DOI: 10.1016/j.ijantimicag.2005.09.002

Darsana, I. G. O., Besung, I. N. K., \& Mahatmi, H. (2012). Potensi daun binahong (Anredera cordifolia (Tenore) Steenis) dalam menghambat pertumbuhan bakteri Escherichia Coli secara In vitro. Indonesia Medicus Veterinus, 1(3), 337-351.

Davis, W. W., \& Stout, T. R., (1971). Disc plate method of microbiological antibiotic assay. Applied Microbiology, 22(4), 666-670. DOI:10.1128/am.22.4.666-670.1971

Ernawati \& Hasmila, I. 2015. Uji fitokimia dan aktivitas antibakteri senyawa metabolit sekunder ekstrak metanol daun mangrove(Rhizophora mucronata). Bionature, 16(2), 98-102. DOI:10.35580/bionature.v16i2.2463

Febrina, L., Riris, I. D., \& Silaban, S. (2017). Activity antibacterial to Escherichia coli and antioxsidant of extract water of leaf binara plant (Artemisia vulgaris L.) after blanching. Jurnal Pendidikan Kimia, 9(2), 311-317. DOI:10.24114/jpkim.vgi2.7621

Juwitaningsih, T., Sari, S. A., Jahro, I. S., Silaban, S., \& Simorangkir, M. (2021). Study of phytochemical, antibacterial activity and toxicity on acetone extract seed Leersia hexandra Sw. Journal of Physics: Conference Series, 1811, 012130. DOI:10.1088/1742-6596/1811/1/012130

Mardiah, A., Alamsyah, Y., \& Kornialia, K. (2017). Pengaruh ekstrak kulit buah jeruk Pontianak (Citrus nobilis L Var Microcarpa) dalam pembentukan zona hambat terhadap pertumbuhan bakteri Streptococcus Mutans. B-Dent: Jurnal Kedokteran Gigi Universitas Baiturrahmah, 4(1), 1-8. DOI:10.33854/JBDjbd.93

Masyhud. (2010). Natioanal Lokakarya Indonesia Medical Plant. Siaran Pers Kementrian Kehutanan Republik Indonesia.

Moat, A.G., Foster, J.W. and Spector, M.P. (2002). Microbial Physiology Fourth Edition. New York: Wiley-Liss.

Monte, J., Abreu, A. C., Borges, A., Simões, L. C., \& Simões, M. (2014). Antimicrobial activity of selected phytochemicals against Escherichia coli and Staphylococcus aureus and their biofilms. Pathogens, 3(2), 473-498. DOI:10.3390/pathogens3020473 
Natheer, S. E., Sekar, C., Amutharaj, P., Rahman, M. S. A., \& Khan, K. F. (2012). Evaluation of antibacterial activity of Morinda citrifolia, Vitex trifolia and Chromolaena odorata. African journal of Pharmacy and Pharmacology, 6(11), 783-788. D0I:10.5897/AJPP11.435

Nurhayati, L. S., Yahdiyani, N., \& Hidayatulloh, A. (2020). Perbandingan pengujian aktivitas antibakteri starter yogurt dengan metode difusi sumuran dan metode difusi cakram. Jurnal Teknologi Hasil Peternakan, 1(2), 41-46. DOI:10.24198/jthp.v1i2.27537

Parekh, J., Jadeja, D., \& Chanda, S. (2006). Efficacy of aqueous and methanol extracts of some medicinal plants for potential antibacterial activity. Turkish Journal of Biology, 29(4), 203-210.

Pelczar, Michael J., \& Chan, E. C. S. (1988). Dasar-dasar mikrobiologi jilid 2. Jakarta: UI Press

Roy, A., Biswas, S. K., Chowdhury, A., Shill, M. C., Raihan, S. Z., \& Muhit, M. A. (2011). Phytochemical screening, cytotoxicity and antibacterial activities of two Bangladeshi medicinal plants. Pakistan Journal of Biological Sciences, 14(19), 905. DOI:10.3923/pjbs.2011.905.908

Sari, R., Muhani, M. \& Fajriaty, I. (2017). Uji aktivitas antibakteri ekstrak etanol daun gaharu (Aquilaria microcarpa Baill.) terhadap bakteri Staphylococcus aureus dan Proteus mirabilis. Pharmaceutical Sciences \& Research, 4(3), 143-154. DOI:10.7454/psr.v4i3.3756

Schlegel, G. Hans. (1993). General Microbiology. Seventh Edition. England: Cambridge University Press.

Simorangkir, M., Nainggolan, B., \& Silaban, S. (2019a). Potensi antibakteri ekstrak n-hexana, etil asetat, etanol daun Sarang banua (Clerodendrum fragrans Vent Willd) terhadap Salmonella enterica. Jurnal Biosains, 5(2), 92-98. DOI:10.24114/jbio.v5i2.13157

Simorangkir, M., Hutabarat, W., Nainggolan, B., \& Silaban, S. (2019b). Antioxidant and antibacterial activities of nonpolar to polar solvent extracts of Sarang Banua (Clerodenrum fragrans Vent Wild) leaves. Rasāyan Journal of Chemistry, 12(02), 959-965. DOI:10.31788/rjc.2019.1225095

Situmeang, B., Ibrahim, A. M., Bialangi, N., Musa, W. J., \& Silaban, S. (2019). Antibacterial activity and phytochemical screening of Kesambi (Sapindaceae) against Eschericia coli and Staphylococcus aureus. Jurnal Pendidikan Kimia, 11(1), 14-17. DOl:10.24114/jpkim.v1111.13078

Utomo, S. B., Fujiyanti, M., Lestari, W. P., \& Mulyani, S. (2018). Antibacterial Activity Test of the C-4methoxyphenylcalix[4]resorcinarene compound modified by HexadecyltrimethylammoniumBromide against Staphylococcus aureus and Escherichia coli bacteria. JKPK (Jurnal Kimia dan Pendidikan Kimia), 3(3), 201. DOI:10.20961/jkpk.v3i3.22742 